\title{
The Efficiency of Impervious Protection of Hydraulic Structures of Irrigation Systems
}

\author{
Bandurin Mikhail A. \\ FSBEI HE Platov South-Russian State Polytechnic \\ University (SRPU) \\ Novocherkassk, Rostov Region, Russia \\ e-mail:chepura@mail.ru
}

\author{
Volosukhin Victor A. \\ FSBEI HE Platov South-Russian State Polytechnic \\ University (SRPU) \\ Novocherkassk, Rostov Region, Russia \\ e-mail:ngma_str_meh@mail.ru
}

\author{
Yurchenko Irina $\mathrm{F}$. \\ FSBSRE All-Russia Research Institute of Hydraulic \\ Engineering and Reclamation by the name \\ of A.N. Kostyakov \\ Moscow, Russia \\ e-mail: irina.507@mail.ru
}

\author{
Mikheyev Alexander V. \\ FSBEI HE Platov South-Russian State Polytechnic University (SRPU) \\ Novocherkassk, Rostov region, Russia \\ e-mail:avmih@mail.ru
}

\begin{abstract}
To prolong the service life of hydraulic structures of irrigation systems and dams there were developed and patented method and device of creating impervious coating of irrigation channels, impervious geotextile coating of low-pressure earthen dams, a device for sealing butt joints of trays providing recovery of water conveyance constructions, operational reliability and durability of impervious coatings, elimination of filtration and leakage in water conveyance constructions. On channels, the result is achieved by using a two-layer coating made of geotextile with a concrete filler. To restore the operational reliability of the butt joints an impervious geotextile coating with a rubber seal is proposed to use. The reliability and durability of impervious geotextile coating for a low-pressure earthen dam are provided by a cellular structure consisting of a bed with a soil filler. Growing from the crest to the foot of the dam, the height of the bed cells eliminates the slipping of the filler which, in turn, prevents the geotextile bed from being damaged. Special attention should be paid to the activities that ensure the reliability and durability of the constructions without decommissioning them. The important task of protection and increase of exploitation safety of reclamation systems and constructions includes the application of modern technologies adaptable to various conditions of reclamation systems exploitation and structural peculiarities of reclamation technologies that provide long-term reliable protection while reducing economic and energy costs. The positive value of the net profit value (NPV) for the period of its use was adopted as a criterion for the effectiveness of the proposed technical operation.
\end{abstract}

Keywords - efficiency criteria, construction, repair, reconstruction, hydraulic structures.

\section{INTRODUCTION}

A priority for the maintenance department responsible for the exploitation of reclamation water utilization system is to ensure the reliability of reclamation facilities that meet the highest standards of forming and transforming the presenttime reclamation fund [1]. Innovative technologies of construction, repair and reconstruction of existing hydraulic structures come to the foreground. Special attention should be paid to the activities that ensure the reliability and durability of the constructions without decommissioning them [2].

When planning the repair or reconstruction activities for the objects, the maintenance department has a certain difficulty in assessing the environmental and economic efficiency of the considered technological solutions, methods, ways and materials that are often crucial to the selection of a particular activity.

In this context, it is right to start a wide campaign to promote the applied approaches and the results of the efficiency evaluation of the technical operation of water conveyance structures in irrigation systems that can improve the level of information support for management decisions [3] and, consequently, their quality.

The important task of protection and increase of exploitation safety of reclamation systems and constructions includes the application of modern technologies adaptable to various conditions of reclamation systems exploitation and 
structural peculiarities of reclamation technologies that provide long-term reliable protection while reducing economic and energy costs, characterized by the absence of toxicity to the biocenosis of soil and water, adaptability of its application.

In the water construction of the RF it becomes widely spread to use facilities made of textile [4], which includes more and more domestic fabric with a various coating (rubber and polymer) to meet the requirement of water permeability and is produced by Russian chemical plants of polymer components and structures (table 1).

TABLE I. CHARACTERISTICS OF MODERN GEOSYNTHETIC MATERIALS FOR WATER CONVEYANCE STRUCTURES

\begin{tabular}{|c|c|c|c|c|c|}
\hline Name & $\begin{array}{c}\text { Manufactu } \\
\text { ring } \\
\text { material }\end{array}$ & $\begin{array}{c}\text { Thic } \\
\text { knes } \\
\text { s } \\
(\mathbf{m m} \\
\text { ) }\end{array}$ & $\begin{array}{c}\text { Tensile } \\
\text { force } \\
(\mathbf{k N} / \\
\mathbf{m})\end{array}$ & $\begin{array}{l}\text { Bursting } \\
\text { strength } \\
\text { (N) }\end{array}$ & $\begin{array}{c}\text { Surface } \\
\text { density } \\
\left(\mathrm{g} / \mathbf{m}^{2}\right)\end{array}$ \\
\hline $\begin{array}{l}\text { Geome } \\
\text { mbrane }\end{array}$ & $\begin{array}{c}\text { Polyethylen } \\
\text { e, } \\
\text { Polyvinyl } \\
\text { chloride, } \\
\text { Butyl } \\
\text { rubber }\end{array}$ & $\begin{array}{l}1.0- \\
3.4\end{array}$ & $27-84$ & $330-970$ & $940-980$ \\
\hline \multirow[b]{2}{*}{$\begin{array}{l}\text { Geotext } \\
\text { iles }\end{array}$} & $\begin{array}{c}\text { Woven. } \\
\text { Polypropyle } \\
\text { ne }\end{array}$ & $\begin{array}{c}0.6- \\
3.2\end{array}$ & $\begin{array}{l}110- \\
1100\end{array}$ & - & $340-2110$ \\
\hline & $\begin{array}{l}\text { Nonwoven } \\
\text { needle- } \\
\text { punched } \\
\text { Polypropyle } \\
\text { ne } \\
\text { Fiberglass }\end{array}$ & $\begin{array}{l}2.0- \\
5.0\end{array}$ & $\begin{array}{l}6.0- \\
28.0\end{array}$ & $500-2500$ & $400-1000$ \\
\hline $\begin{array}{c}\text { Geogri } \\
\text { d }\end{array}$ & $\begin{array}{c}\text { Polyethylen } \\
\text { e }\end{array}$ & $\begin{array}{l}1.5- \\
2.5\end{array}$ & $\begin{array}{l}18.5- \\
30.0\end{array}$ & - & $940-980$ \\
\hline
\end{tabular}

Their products consisting as of one- and the two-layer fabric has a mass of $1 \mathrm{~m}^{2}$ if the weight is from 1.2 to $3.5 \mathrm{~kg}$ and the thickness of nylon fabric is from 0.9 to $3.0 \mathrm{~mm}$ [5]. The hydrotechnical structures, consisting of them and for which they are used, are mainly seasonal or temporary according to the classification.

The abroad water-related constructions use heavy fabrics, which are characterized by increased durability and are classified as permanent according to the classification. The USA uses two- and three-layer materials, the production of which is established by famous manufacturers: DuPont, Hudler, Firestone, etc., with a mass of $1 \mathrm{~m}^{2}-$ from 2.4 to 7.2 $\mathrm{kg}[6]$.

Assessment of the production by different manufacturers shows that hydraulic engineering, in recent years, has a tendency to use more and more structures made of composites, characterized by high strength characteristics and ability to resist harmful influences. For this purpose various additives are introduced: Mineral substances (coal, lime fillers, clay shale powder), stabilizers (technical carbon), plasticizers, fungicides, herbicides, microbicides, fibres and elastomers, etc. Depending on the classification, their strength can be changed in characteristics from 100 to $1000 \mathrm{kN} / \mathrm{m}$.
Reinforcement of coatings is carried out to impart strength during manufacturing, increase their operational strength (to check any tensile, tear, bursting, cuts, etc.), as well as to increase the modulus of elasticity. The coating is considered to be reinforced if the materials used for this purpose are distributed evenly across the surface, the reinforcement can be made of non-woven or woven geotextiles, geogrids - made of polyester and fibreglass [7].

In connection with the peculiarities of fabric structures, the domestic plants RTI (producing general rubber goods) mainly use synthetic fabrics textile in the water sector: nylon, polyamide, viscose, acrylonitrile and others belonging to the group of heavy fabric (with the weight of $800-1600 \mathrm{~g} / \mathrm{m}^{2}$ ) with short-term tensile strength of $40 \ldots 300 \mathrm{kN} / \mathrm{m}$.

To the present date, the general theory of the mechanical properties of polymers is not fully developed [8], due to their relatively recent spread and non-traditional properties to compare with the usual material. At considerable deformations and fast increase of tension, the elasticity of polymers cannot be described by the law of Hooke and fluidity - by Newton's law; the deformation-stress dependence graphs nonlinearly vary from the speed of deformation.

Hydraulic structures made of textiles are classified according to the following categories of parameters:

a) the manufacturing facility material - fabric, the method of thread interlacing, the number of the levels and the type of replacement;

b) the material with preventive function - types of rubber impregnation, the application technique, the number of impregnation levels;

The analysis of the rubberized fabric nomenclature enables selecting the types suitable for use in the water sector. Table 2 shows the normative performance of these fabric materials from JSC "UZEMIK" (Ufa plant of RTI). The given normative values of breaking loads and elongations are assigned with a considerable reserve. The soft structures produced by JSC "Uzemik" for water management are made of 80 and $50 \mathrm{kn} / \mathrm{M}$ fabrics [9].

This paper presents the resulting materials of design and assesses the feasibility of introducing geotextile coatings to ensure the efficiency of irrigation system channels and reduction of filtration earthen dams at reclamation water utilization system. The purpose of the research is to improve information security measures of impervious protection in construction, repair and reconstruction of hydraulic structures of irrigation systems.

\section{MATERIALS AND METHODS}

According to the results of the study, synthesis and analysis of theory, practical results and experiences of the service operation in terms of prolonging the service life of hydraulic structures as a part of the research, there are developed and patented the following issues: the method and apparatus of creating impervious geotextile coating of irrigation channels and low-pressure earthen dams, as well as a device for sealing butt joints of the trays. The proposed 
technical solutions ensure the recovery of water conveyance structures, operational reliability and durability of impervious surfaces of the channels, fixing the filtration and leakage at water conveyance structures, and they successfully passed testing at irrigation systems of the South of Russia in the FSBI department "Rostovmeliovodkhoz", "Kubanmeliovodkhoz" and "Stavropolmeliovodkhoz" in the process of repairing the reclamation water utilization system [10].

TABLE II. PHYSICAL AND MECHANICAL CHARACTERISTICS OF THE IMPERVIOUS COATING OF THE WALLS OF WATER CONVEYANCE CHANNELS

\begin{tabular}{|c|c|c|c|}
\hline Parameter & Units & Method & $\begin{array}{c}\begin{array}{c}\text { Param } \\
\text { eter }\end{array} \\
\end{array}$ \\
\hline Thickness & $\mathrm{mm}$ & $\begin{array}{c}\text { GOST 10354-82 } \\
\text { DIN EN ISO 53353 }\end{array}$ & $1.0-3.0$ \\
\hline $\begin{array}{c}\text { The width of the } \\
\text { fabric }\end{array}$ & $\mathrm{m}$ & GOST 10354-82 & $1,5-8,0$ \\
\hline $\begin{array}{l}\text { The length of the } \\
\text { fabric in a roll }\end{array}$ & $\mathrm{m}$ & GOST 10354-82 & $50-100$ \\
\hline $\begin{array}{c}\text { The content of soft } \\
\text { thermal carbon }\end{array}$ & $\%$ & $\begin{array}{c}\text { ASTM-D-1603-94 } \\
\text { GOST 10354-82 }\end{array}$ & $2-3$ \\
\hline Tension load & $\mathrm{MPa}$ & DIN EN ISO 527-3 & $\begin{array}{l}\text { not } \\
\text { less } \\
\text { than } \\
13.5 \\
\end{array}$ \\
\hline $\begin{array}{l}\text { Breaking } \\
\text { elongation }\end{array}$ & $\%$ & DIN EN ISO 527-3 & $\begin{array}{c}\text { not } \\
\text { less } \\
\text { than } \\
450\end{array}$ \\
\hline Frost resistance & ${ }^{\circ} \mathrm{C}$ & $\begin{array}{l}\text { GOST 10354-82 } \\
\text { DIN EN 1876-1 }\end{array}$ & $\begin{array}{c}\text { not } \\
\text { less } \\
\text { than } \\
(-50) \\
\end{array}$ \\
\hline $\begin{array}{l}\text { Softening } \\
\text { temperature }\end{array}$ & ${ }^{\circ} \mathrm{C}$ & $\begin{array}{l}\text { GOST 10354-82 } \\
\text { DIN EN 1876-1 }\end{array}$ & $\begin{array}{c}\text { Not } \\
\text { less } \\
\text { than }(+ \\
100)\end{array}$ \\
\hline Bursting resistance & $\mathrm{N}$ & ASTM-D-4833 & $\begin{array}{l}\text { Not } \\
\text { less } \\
\text { than } \\
250 \\
\end{array}$ \\
\hline
\end{tabular}

In accordance with the principle of integrity, declaring the management process continuity: diagnostics, prognosis, planning, impact, control, in the structure of researches we developed the methods of restoration and prolongation of the operational resource of water conveyance structures within irrigation systems based on impervious protection.

Improving the efficiency of using geotextile coatings to extend the service life of water conveyance structures due to the efficiency and durability of impervious surfaces [11]. To reduce the waste of water for the channels we offered an impervious geotextile coating with a concrete filler. Figure 1 depicts the geotextile coating of channels in section; figure 2 the same (overhead plan view).

The double-layer coating of the geotextile material (3) stretches upon the underlain soil (1) across the perimeter of the water conveyance channel. It consists of two panels, connected by local longitudinal seams (5), are checkerboardarranged to achieve an even distribution throughout the double-layer concrete coating (2), fed through a tube (4), and are located at the edge of a panel, fixed on the edge of the ditch.

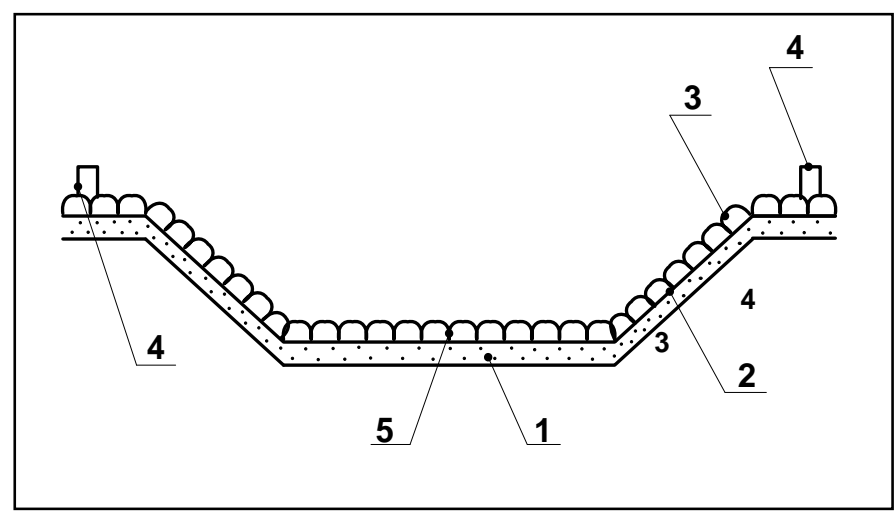

Fig. 1. Imperviops geotextile coating of water conveyance channels: crosssection: 1 - underlying terrain; 2 - containers for concret 2 -geotextile material; 4 - throat section; 5 - local longitudinal joint.

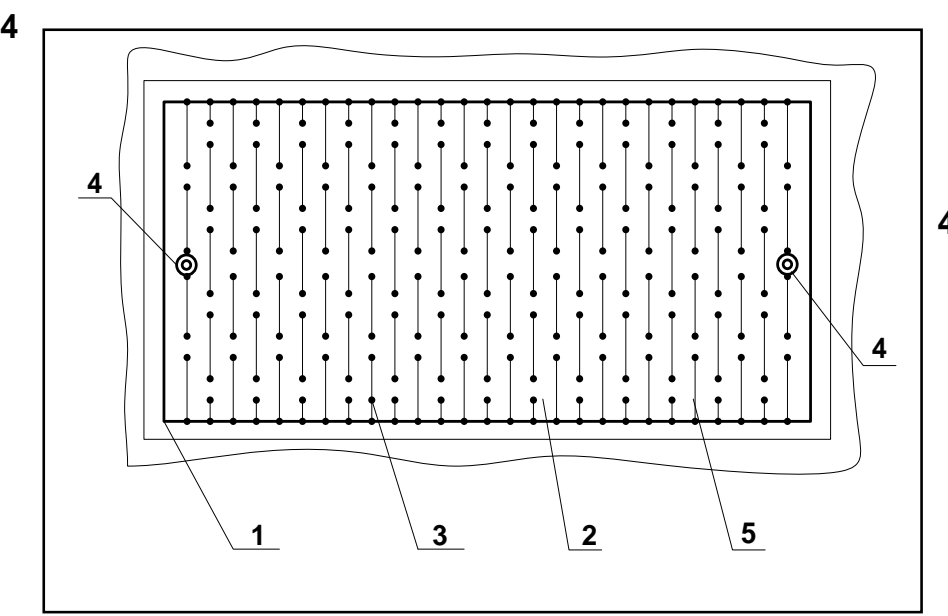

Fig. 2. Geotextile coating of main, inter-farm and on-farm channels, overhead plan view: 1 - underlying terrain; 2 - containers for filling; 3 geotextile material; 4 - throat section; 5 - local longitudinal joint.

The service life of such coating is provided by its rigidity and strength due to the properties of concrete (2) and the application method of the geotextile material (3). Concrete, stiffening, gives rigidity and durability to the whole coating structure. The double layer of geotextiles increases the reliability of protection against the water loss through seepage from water conveyance channels [12]. If during the operation, the upper (facing water) panel, the further filtration is prevented by the bottom geotextile panel.

To restore the operational reliability of the butt joints of trays and pipelines, tunnels and storm drainage systems we proposed impervious geotextile coating (Fig. 3) consisting of metal plates (1), geotextile fabric (2) and a rubber seal (3). A coating for sealing butt joints is further provided with mounting clamps (4) and set-screws (5), galvanized metal panel made in a form echoing the shape of the tray.

Impervious geotextile coating for sealing butt joints of trays and pipelines is mounted in the following way. Butt joints of two trays 4 are laid upon with a rubber strip 3, and then with a top metal panel and geotextile fabric 2 . On the upper edge of the tray, there are installed mounting clamps 1 and a metal plate is squeezed by means of set-screws to the 
tray repeating its shape. The force is generated which presses the panel to the butt joint, protecting the connection place from destruction. The use of a geotextile coating to seal breaks and damages of butt joints of trays and pipelines extends the capacity of the hydraulic structure, as well as provides urgent liquidation of the emergency condition due to the short duration of installation and jointing.

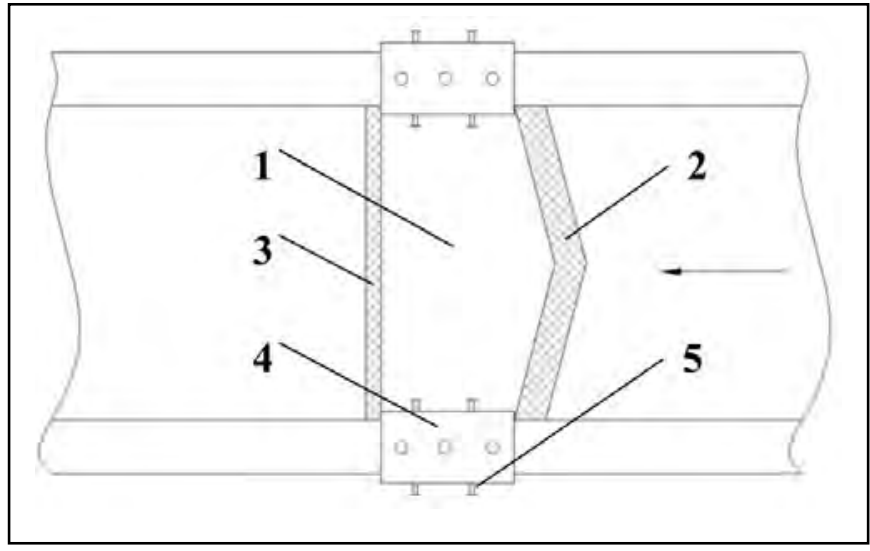

4

Fig. 3. Impervious geotextile coating for sealing butt joints: the view from the top: 1 - metal panel; 2 - geotextile fabric; 3 - rubber seal; 4 - mounting clamps; 5 - set-screws.

To repair coatings of main and inter-farm irrigation channels we propose cellular geotextile coating [13]. Its operatiofal reliability and durability are provided by the cellular structure of the geotextile coating (3) filled with soil (4). The soil protects a geotextile Material (2) from damage, and the geotextile material itself prevents the water loss through filtration from water conveyance channels (Fig. 4).

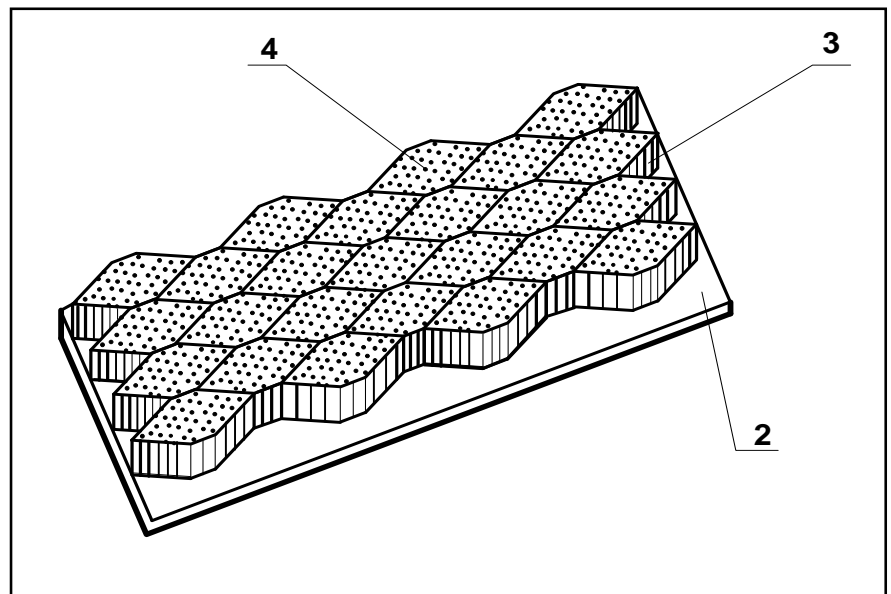

Fig. 4. Impervious cellular geotextile coating of water conveyance channels and low-pressure flood-breaking dams: 2 - geotextile material; 3 - cellular structure; 4 - soil filling.

Фиг.2

The stability of the geotextile coating of a low-pressure earthen dam (Fig. 5) is achieved with the use of a cellular structure (5), with the variable depth of a cell, increasing from the crest (3) to the foot of the dam (4) when $t_{2}>t_{1}$, where $t_{1}$ is the depth of the cell on the crest of the dam and $t_{2}-$ the depth of the cell at the foot of the dam. Such a structure prevents slipping of the cell filling soil (7) and protects geotextiles (5) from the negative impact. In turn, waterproof geotextiles reduce the loss of water for filtration [14].

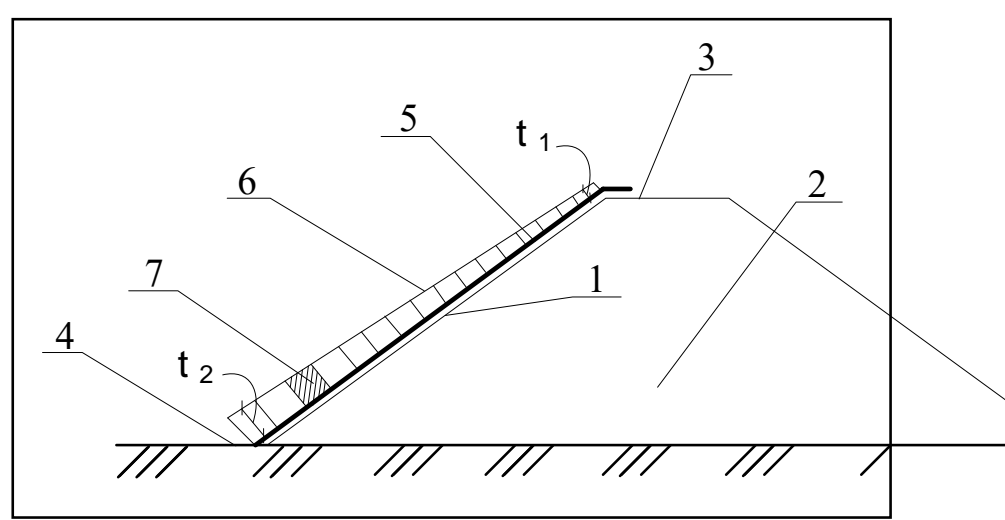

Fig. 5. Impervious geotextile coating of low-pressure earthen dams: 1 underlain soil; 2 - low-pressure earthen dam; 3 - crest of the dam; 4 - foot of the dam; 5 - the geotextile layer; 6 - adjustable cellular structure; 7 - soil filling.

An important advantage, determining the socio-economic feasibility of application of the developed methods to protect the structures, is the possibility of urgent elimination of violations in the structural elements without interrupting its operation in cases of emergency, that caused the failure of water conveyance structures in the vegetation period, and to reduce the possibility of damages.

These include the damage caused by the loss of crops due to under-watering (destruction of the water conveyance facility elements), excessive water use (due to leaks in the places of destruction till identifying the damage and blocking the channel), expenses associated with the complete replacement of the item in case of its destruction.

Economic efficiency of using the impervious geotextile coating of main and inter-farm channels and low-pressure earthen dam was calculated in accordance with the provisions of Methodical recommendations on estimating the efficiency of investment projects on agricultural land reclamation (RD APK3.00.01.003-03) based on the methodology and fundamental principles for determining the efficiency of investment, developed in the successful areas of the economy in Russia and abroad.

The positive value of the net profit value (NPV) for the period of its use was adopted as a criterion for the event effectiveness [15].

$$
\mathrm{NPV}=\sum_{m} f_{m} \alpha_{m} \geq 0
$$

where $\sum \mathrm{f}_{\mathrm{m}}$ is a discount net balance for a net profit value at the $m$ step.

$\mathrm{a}_{\mathrm{m}}-$ the discount factor. The amount $\sum$ includes all the steps of the operating period. 
$\mathrm{m}$ is the number of years within a step of the general billing period which is usually taken as the period equal to 30 years.

$$
\alpha_{\mathrm{m}}=1 /(1+\mathrm{E}) \mathrm{m}
$$

where $\mathrm{E}$ is the discount rate equal to $8 \%$ for the public efficiency assessment.

The balance for net profit value for each step was calculated based on the outcomes available before the implementation of the proposed activities. As an effect there was used the amount of the prevented damage from the application of the impervious geotextile coatings, as costs the cost of repairing and operating the construction [13]. The initial data for calculating the efficiency of the implemented activity are described in Table 3

TABLE III. INITIAL DATA FOR CALCULATING THE EFFICIENCY OF THE IMPERVIOUS GEOTEXTILE COATING OF WATER CONVEYANCE STRUCTURES IN IRRIGATION SYSTEMS

\begin{tabular}{|c|c|c|c|}
\hline \multirow{2}{*}{ Indicators } & \multirow{2}{*}{ Units } & \multicolumn{2}{|c|}{ Values } \\
\hline & & $\begin{array}{l}\text { Before } \\
\text { repair }\end{array}$ & $\begin{array}{l}\text { After } \\
\text { repair }\end{array}$ \\
\hline Channel consumption * & $\mathrm{m}^{3} / \mathrm{s}$ & 10 & 10 \\
\hline $\begin{array}{l}\text { Duration of water supply for } \\
\text { vegetation }(86 * 400 * 30 * 4)\end{array}$ & from & $10.3710^{6}$ & $10.3710^{6}$ \\
\hline Water consumption for filtration ${ }^{*}$ & $1 / \mathrm{s}$ & 20 & 10 \\
\hline $\begin{array}{l}\text { The reduction of water losses } \\
\left(0.01 * 10.3710^{6}\right)\end{array}$ & $\begin{array}{c}\begin{array}{c}\text { thousand } \\
\mathrm{m}^{3} / \mathrm{km}\end{array} \\
\end{array}$ & - & 103.7 \\
\hline Specific cost of the supply ${ }^{*}$ & $\mathrm{rub} / \mathrm{m}^{3}$ & 0.18 & 0.18 \\
\hline Damage prevented by water loss & $\begin{array}{c}\text { thousand } \\
\text { rubles } / \mathrm{k} \\
\text { m per } \\
\text { year }\end{array}$ & - & 18.7 \\
\hline $\begin{array}{l}\text { Balance cost: main and inter-farm } \\
\text { channels }\end{array}$ & $\begin{array}{c}\text { thousand } \\
\mathrm{m} 3 / \mathrm{km}\end{array}$ & 125 & - \\
\hline Balance cost: low-pressure dams & $\begin{array}{c}\text { thousand } \\
\mathrm{m} 3 / \mathrm{km}\end{array}$ & 19.6 & - \\
\hline $\begin{array}{l}\text { The cost of the repair: main and } \\
\text { inter-farm channels* }\left(0.4^{*} 125\right)^{*}\end{array}$ & $\begin{array}{c}\text { thousand } \\
\mathrm{m} 3 / \mathrm{km}\end{array}$ & - & 50 \\
\hline $\begin{array}{l}\text { The cost of the repair: low- } \\
\text { pressure dams }(0.43 * 19.6) *\end{array}$ & $\begin{array}{c}\text { thousand } \\
\mathrm{m} 3 / \mathrm{km}\end{array}$ & - & 8.5 \\
\hline $\begin{array}{l}\text { Operating costs: main and inter- } \\
\text { farm channels* }\end{array}$ & $\begin{array}{l}\text { thousand } \\
\mathrm{m} 3 / \mathrm{km}\end{array}$ & & $1.0^{*}$ \\
\hline $\begin{array}{l}\text { Operating costs: low-pressure } \\
\text { dams * }\end{array}$ & $\begin{array}{c}\text { thousand } \\
\mathrm{m} 3 / \mathrm{km}\end{array}$ & & 0.25 \\
\hline $\begin{array}{l}\text { The service life of a protective } \\
\text { geotextile coating }\end{array}$ & in years & & \\
\hline Discount rate & $\%$ & & \\
\hline
\end{tabular}

*Taken according to the maintenance department on the land reclamation in the South of Russia.

The results of calculating the ecological and economic efficiency [16] of implementing the measures for the protection of channels and low-pressure dams with geotextile coatings clearly demonstrate the environmental and economic feasibility of their implementation (Fig. 5).

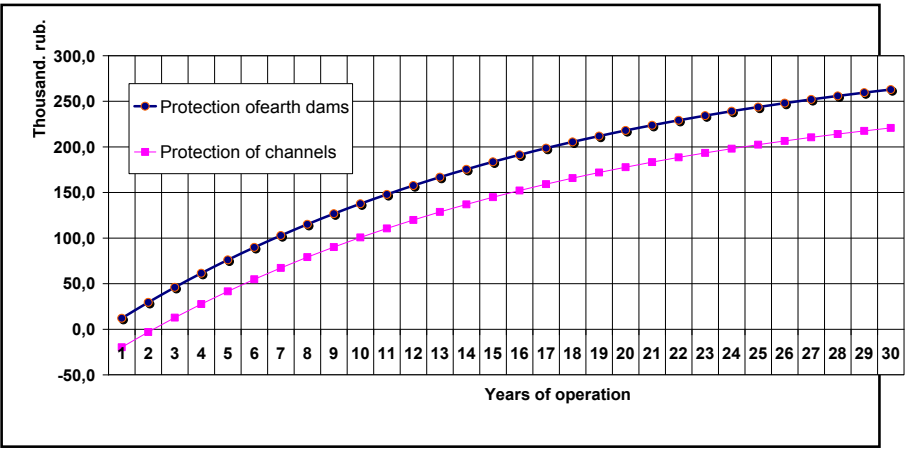

Fig. 6. Ecological and economic efficiency of the impervious geotextile coating of water conveyance structures in irrigation systems, thousand rub. / $\mathrm{km}$.

The net profit value balance over a 30 -year period of operating the renovated structures is quite positive and make 210.6 thousand $\mathrm{rub} / \mathrm{km}$ from the application of geotextiles for channels and 262.8 thousand $\mathrm{rub} / \mathrm{km}$ for earthen dams. The payback period of total capital investments [17] according to the increase in net income and accounting for the discount is about one year and a half and is less than a year in terms of the measures to protect earthen channels and dams.

\section{CONCLUSION}

The high rating of the efficiency of the impervious geotextile coatings of water conveyance structures in irrigation systems, calculated in this work, is proved by the data from the maintenance department at FSBI on reclamation of the Rostov region, Krasnodar territory and other regions of the Russian Federation, testing these coatings at the subordinate territories. This gives grounds to recommend the approaches applied to the above-mentioned researches when calculating the environmental and economic efficiency of technical operation of hydraulic structures to achieve a broad introduction into the reclamation practice.

\section{References}

[1] L.V. Kireicheva, Scientific foundations of creation and management of reclamation systems in Russia, Moscow: FGBNU VNII agrokhimii, 2017

[2] M.A. Bandurin, I.F. Yurchenko, V.A. Volosukhin, V.V. Vanzha, Ya.V. Volosukhin, "Ecological and economic efficiency of diagnostics of technical condition of water supply facilities of irrigation systems", J. Ecology and Industry of Russia, vol. 22(7), pp. 66-71, 2018.

[3] L.V. Kirejcheva, New technologies of designing, substantiation of construction, operation and management of land reclamation systems, Moscow: VNIIA, 2010

[4] Md.M. Alam, C. Wagner, "The Relative Importance of Monetary and Non-Monetary Drivers for Information and Communication Technology Acceptance in Rural Agribusiness." Information Technology for Development, pp. 1-18, 2016.

[5] V.I. Olgarenko, G.V. Olgarenko, I.V. Olgarenko, "Integrated assessment of the technical level of the irrigation and drainage systems", Melioration and water management, vol. 6, pp. 8-11, 2013.

[6] Marchewka "Information Technology Project Management. John Wiley \& Sons, 2014

[7] V.I. Olgarenko, I.V. Olgarenko, V.I. Selyukov, "Computer technology of planning water use in irrigation systems", Bulletin of the Russian Academy of Agricultural Sciences, vol. 4, pp. 12-15, 2012. 
[8] A. Khmelyak, "Information systems of enterprise management: positive and negative aspects of implementation", Actual questions of economic sciences, vol.35, pp. 182-186, 2013.

[9] V.A. Volosukhin, M.A. Bandurin, V.V. Vanzha, A.V. Mikheev, Y.V. Volosukhin, "Numerical analysis of static strength for different damages of hydraulic structures when changing stressed and strained state", Journal of Physics: Conference Series, 1015(4), 2018, 042061.

[10] E.B. Kolbachev, M.V. Perederiy, "Planning the development of organizational structures and business processes as an innovative task", Bulletin of the South Russian State Technical University (Novocherkassk Polytechnic Institute). Series: Socio-economic sciences, vol. 1, pp. 4-10, 2015.

[11] E.B. Kolbachev, M.V. Perederiy, "Natural sciences and engineering methods in the institutional economy", Scientific and technical lists of the St. Petersburg State Polytechnic University, Economic Sciences, vol. 6-2 (185), pp. 23-27, 2013.

[12] T. Nguyen, H. Newby, M. Macaulay, "Information Technology Adoption in Small Business: Confirmation of a Proposed Framework". Journal of Small Business Management, vol. 53, Issue 1, pp. 207-227, 2015
[13] O.G. Degtyareva, D.A. Dac'o, G.V. Degtyarev, A.D. Gumbarov, "Design in cae system of low-head weir tiled foundation sinking", Proceedings of the Kuban State Agrarian University, vol. 64, pp. 221226, 2017.

[14] O. Degtyareva, G. Degtyarev, I. Togo, V. Terleev, A. Nikonorov, Yu. Volkova, "Analysis of stress-strain state rainfall runoff control system buttress dam", Procedia Engineering, vol. 165, pp. 1619-1628, 2016.

[15] F.K. Abdrazakov, N.F. Ryzhko, S.N. Ryzhko, S.A. Horin, S.V. Botov, "Electricity consumption decrease at pump stations during watering by multi-support sprinkling units", Journal of Fundamental and Applied Sciences, vol. 10, pp. 1464-1481, 2018.

[16] B.P. Chesnokov, O.V. Naumova, V.A. Strelnikov, F.K. Abdrazakov, B.A. Tronin, "Polyethylene production from granules using high voltage", International Journal of Applied Engineering Research, vol. 11, pp. 2140-2144, 2016.

[17] P.P. Gaydzhurov, S.F. Al-Dzhabobi, M.A. Al-Khadzh, "Finite-element modelling of force transmission the tension of the steel tendon on the concrete", News of Higher Educational Institutions of North Caucasus region, vol. 2, pp. 73-78, 2017. 